\title{
Measuring the impact of service quality on post-purchase intention
}

\author{
Parichehr Yarahmadi Dehnavi $^{\mathrm{a}^{*}}$, Ali Mollahosseini ${ }^{\mathrm{b}}$ and Mohammadali Forghani ${ }^{\mathrm{c}}$
}

${ }^{a}$ Student of Executive Master of Business Administration, Department of Management, Shahid Bahonar Univresity, Kerman, Iran

${ }^{b}$ Professor of Management Department, Shahid Bahonar Univresity, Kerman, Iran 3Assistant

${ }^{c}$ Assistant Professor of Management Department, Shahid Bahonar Univresity, Kerman, Iran

\section{H R O N I C L E}

Article history:

Received January 28, 2014

Accepted 20 June 2014

Available online

June 292014

Keywords:

Service Quality

Customer Satisfaction

Post-Purchase Intention

SMEs

\section{A B S T R A C T}

\begin{abstract}
This paper presents an empirical investigation to study the effects of service quality on postpurchase intention. The study is applied among some small and medium enterprises (SMEs) in city of Kerman, Iran. There were approximately 300 people working for these units and the study chose 168 people as a sample study. The study used a standard questionnaire consists of 20 questions in Likert scale and distributed it among the sample size. Using structural equation modeling the study has determined that service quality as well as perceived quality influenced positively on customer satisfaction and post-purchase intention.
\end{abstract}

(C) 2014 Growing Science Ltd. All rights reserved.

\section{Introduction}

The phenomenon of declining in customer satisfaction (Parasuraman et al., 1985, 1988) and loyalty becomes the primary concern of the service companies because the two factors determine the performance of the firms (Segoro, 2013). Customer satisfaction plays essential role on business development and there are several studies associated with relationship between these two components (Wu \& Liang, 2009). Demirci Orel and Kara (2014), for instance, studied supermarket self-checkout service quality, customer satisfaction, and loyalty. They reported that self-checkout systems service quality positively influenced loyalty through the customer satisfaction path. Kuo et al. (2009) built a framework to evaluate service quality of mobile value-added services and maintained a further discussion of the relationships among service quality, perceived value, customer satisfaction, and post-purchase intention. They reported that service quality positively influenced both perceived value and customer satisfaction. In addition, in their study, perceived value positively influenced on both customer satisfaction and post-purchase intention.

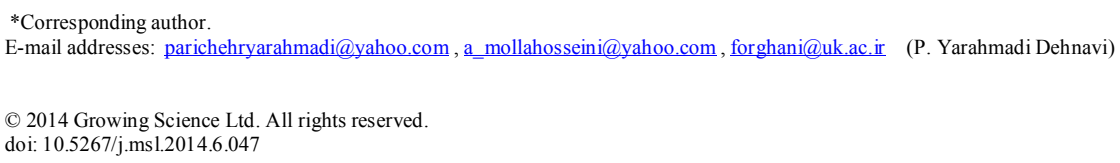


Grissemann and Stokburger-Sauer (2012) developed a conceptual model of customer co-creation of tourism services and empirically examined this model in a travel agency context. Udo et al. (2010) investigated the dimensions of web service quality based on e-customer's, expectations and perceptions. They developed operationalized web service quality constructs, and analyzed, their relationships with customer satisfaction and behavioral intentions in an e-business environment. They reported the indirect or mediating effect of satisfaction on web, service quality and behavioral intentions appeared to be stronger than the direct effect of web service, quality on behavioral intentions. Jung and Yoon (2013) investigated whether employees' satisfied customers may respond with an satisfactory relationship. They studied the effects of employees' satisfaction on customers' satisfaction and loyalty in a family restaurant. Their results indicated a positive relationship between employees' satisfaction and customer satisfaction. However, employees' satisfaction did not maintain a significant, direct effect on customer loyalty, but represented an indirect effect via customer satisfaction.

\section{The proposed study}

This paper presents an empirical investigation to study the effects of service quality on post-purchase intention. The study is applied among some small and medium enterprises (SMEs) in city of Kerman, Iran. The sample size for the proposed study of this paper is calculated as follows,

$$
n=\frac{N \times z_{\alpha / 2}^{2} \times p \times q}{\varepsilon^{2} \times(N-1)+z_{\alpha / 2}^{2} \times p \times q},
$$

where $N$ is the population size, $p=1-q$ represents the yes/no categories, $z_{\alpha / 2}$ is CDF of normal distribution and finally $\varepsilon$ is the error term. Since we have $p=0.5, z_{\alpha / 2}=1.96$ and $N=300$, the number of sample size is calculated as $n=168$. The study use a standard questionnaire consists of 20 questions in Likert scale and distributes it among the sample size. Fig. 1 shows the propsoed study of this paper.

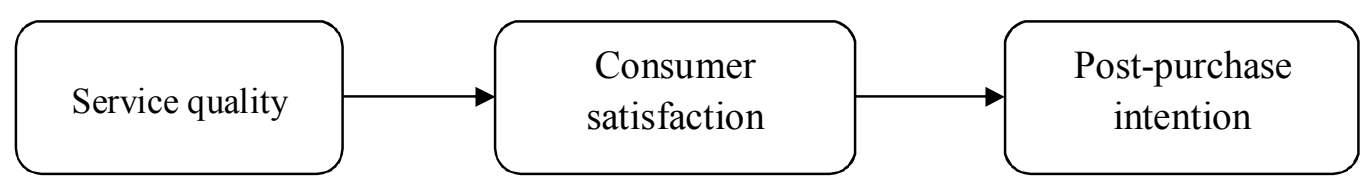

Fig. 1. The proposed study

According to Fig. 1, service quality influences on consumer satisfaction and consumer satisfaction, in turn, influences on post-purchase intention. There are three hypotheses for the proposed study as follows,

1. Service quality influences positively on customer satisfaction.

2. Customer satisfaction influences positively on post-purchase intention.

3. Service quality influences positively on post-purchase intention.

The study distributes a number of questionnaires among some experts and measures Cronbach alphas for three components of the survey. Table 1 demonstrates the results of our findings.

\section{Table 1}

The summary of Cronbach alpha

\begin{tabular}{lll}
\hline Variable & Alpha & Result \\
\hline Service quality & 0.993 & Confirmed \\
Customer satisfaction & 0.974 & Confirmed \\
Post-purchase intention & 0.976 & Confirmed \\
\hline
\end{tabular}


As we can observe from the results of Table 1, all components of the survey are within desirable levels. The study uses structural equation modeling to verify the hypotheses of the survey and Table 2 demonstrates the results of some statistical observations.

Table 2

Fit indexes of model

\begin{tabular}{cccccccccc}
\hline Index & P_value & $\chi^{2} /$ df & RMSEA & CFI & NFI & NNFI & GFI & IFI & RMR \\
\hline Acceptable Value & $<0.05$ & $<5$ & $<0.1$ & $>0.9$ & $>0.9$ & $>0.9$ & $>0.9$ & $>0.9$ & $<0.05$ \\
Value & 0.00 & 1.47 & 0.044 & 0.976 & 0.974 & 0.99 & 0.927 & 0.976 & 0.030 \\
\hline
\end{tabular}

As we can observe from the results of Table 2, all statistical observations are within acceptable limits.

\section{The results}

In this section, we present details of our findings in testing various hypotheses of the survey. Table 3 demonstrates the

Table 3

The summary of SEM statistics

\begin{tabular}{ccccccc}
\hline & & Variable & Non-Standard $\beta$ & Standard error & Standard $\beta$ & Sig. \\
\hline Q1 & $<---$ & SERVICE QUALITY & 1.000 & & .913 \\
Q2 & $<---$ & SERVICE QUALITY & 1.022 & .046 & .937 \\
Q3 & $<---$ & SERVICE QUALITY & .855 & .041 & .000 \\
Q4 & $<---$ & SERVICE QUALITY & .880 & .046 & .923 \\
Q5 & $<---$ & SERVICE QUALITY & .980 & .044 & 0.000 \\
Q6 & $<---$ & SERVICE QUALITY & 1.045 & .046 & .938 & 0.000 \\
Q7 & $<---$ & SERVICE QUALITY & 1.069 & .049 & .945 \\
Q8 & $<---$ & SERVICE QUALITY & 1.081 & .047 & .933 \\
Q9 & $<---$ & SERVICE QUALITY & .979 & .050 & .946 \\
Q10 & $<---$ & SERVICE QUALITY & .975 & .050 & .901 \\
S1 & $<---$ & CUSTOMER SATISFACTION & 1.000 & .000 \\
S2 & $<---$ & CUSTOMER SATISFACTION & 1.176 & .052 & .901 \\
S3 & $<---$ & CUSTOMER SATISFACTION & 1.136 & .046 & .922 \\
S4 & $<---$ & CUSTOMER SATISFACTION & 1.007 & .051 & .937 \\
I1 & $<---$ & POST-PURCHASE INTENTION & 1.000 & .960 \\
I2 & $<---$ & POST-PURCHASE INTENTION & 1.087 & .000 \\
I3 & $<---$ & POST-PURCHASAE INTENTION & 1.138 & .033 & 0.000 \\
\hline
\end{tabular}

As we can observe from the results of Table 3, the questions have positive and meaningful effects. Table 4 and Table 5 demonstrate the results of direct effects.

Table 4

The summary of directs effects

\begin{tabular}{ccccccc}
\hline Variable & & Variable & Non-Standard $\beta$ & Standard error & Standard $\beta$ & Sig. \\
\hline Service Quality & $\rightarrow$ & Customer satisfaction & .441 & .040 & .487 & 0.000 \\
Customer Satisfaction & $\rightarrow$ & Post Purchase intention & .942 & .046 & .943 & 0.000 \\
\hline
\end{tabular}

\section{Table 5}

The summary of indirect effects

\begin{tabular}{|c|c|c|c|c|c|}
\hline & & & $\begin{array}{c}\text { Indirect } \\
\text { estimation }\end{array}$ & $\begin{array}{c}\text { Standard indirect } \\
\text { estimation }\end{array}$ & Sig. \\
\hline Service Quality & $\rightarrow$ & Post Purchase intention & 0.778 & 0.861 & 0.000 \\
\hline
\end{tabular}




\section{Discussion and conclusion}

In this paper, we have presented an empirical investigation to study the effects of service quality on post-purchase intention among some selected employees who worked for SMEs in city of Kerman, Iran. The study has determined that service quality as well as perceived quality influenced positively on customer satisfaction and post-purchase intention. Table 6 summarizes the results of testing various hypotheses of the survey.

\section{Table 6}

The summary of testing various hypotheses

\begin{tabular}{llll}
\hline Hypothesis & Description & $\beta$ & Sig. \\
\hline 1 & Service quality influences positively on customer satisfaction. & 0.487 & 0.001 \\
2 & Customer satisfaction influences positively on post-purchase intention. & 0.943 & 0.001 \\
3 & Service quality influences positively on post-purchase intention. & 0.861 & 0.001 \\
\hline
\end{tabular}

The results of this survey are consistent with other findings reported by Demirci Orel and Kara (2014) and Kuo et al. (2009).

\section{Acknowledgement}

The authors would like to thank the anonymous referees for constructive comments on earlier version of this paper.

\section{References}

Demirci Orel, F., \& Kara, A. (2014). Supermarket self-checkout service quality, customer satisfaction, and loyalty: Empirical evidence from an emerging market. Journal of Retailing and Consumer Services, 21(2), 118-129.

Grissemann, U. S., \& Stokburger-Sauer, N. E. (2012). Customer co-creation of travel services: The role of company support and customer satisfaction with the co-creation performance. Tourism Management, 33(6), 1483-1492.

Kuo, Y. F., Wu, C. M., \& Deng, W. J. (2009). The relationships among service quality, perceived value, customer satisfaction, and post-purchase intention in mobile value-added services. Computers in human behavior, 25(4), 887-896.

Jung, H. S., \& Yoon, H. H. (2013). Do employees' satisfied customers respond with an satisfactory relationship? The effects of employees' satisfaction on customers' satisfaction and loyalty in a family restaurant. International Journal of Hospitality Management, 34, 1-8.

Parasuraman, A., Zeithaml, V. A., \& Berry, L. L. (1985). A conceptual model of service quality and its implications for future research. the Journal of Marketing, 41-50.

Parasuraman, A., Zeithaml, V. A., \& Berry, L. L. (1988). Servqual. Journal of retailing, 64(1), 12-40.

Segoro, W. (2013). The influence of perceived service quality, mooring factor, and relationship quality on customer satisfaction and loyalty. Procedia-Social and Behavioral Sciences, 81, 306310.

Udo, G. J., Bagchi, K. K., \& Kirs, P. J. (2010). An assessment of customers'e-service quality perception, satisfaction and intention. International Journal of Information Management, 30(6), 481-492.

Wu, C. H. J., \& Liang, R. D. (2009). Effect of experiential value on customer satisfaction with service encounters in luxury-hotel restaurants. International Journal of Hospitality Management, 28(4), 586-593. 